International Journal of Social Science (IJSS)

Vol.1 Issue.5 February 2022, pp: 553-562

ISSN: 2798-3463 (Printed) | 2798-4079 (Online)

\title{
THE EFFECTIVENESS OF BALI TOURISM PROMOTION THROUGH OUT DIGITAL MARKETING VIDEOS
}

\author{
By \\ Herry Arianto ${ }^{1}$, I Gede Pitana ${ }^{2}$, Agung Suryawan Wiranatha ${ }^{3}$, Made Budiarsa ${ }^{4}$ \\ 1,2,4 Tourism Doctoral Program, Udayana University \\ ${ }^{3}$ Center of Excellence of Tourism, Udayana University \\ Email: ${ }^{1}$ paulus.herry@gmail.com
}

\begin{tabular}{l}
\hline \hline Article Info \\
\hline Articlehistory: \\
Received Nov 17, 2021 \\
Revised Dec 22, 2021 \\
Accepted Jan 18, 2021
\end{tabular}

Keywords:

Digital Video Marketing, Bali

Tourism, AISAS

\begin{abstract}
The advances in science and technology have also influenced the development of Bali tourism promotion strategies. In digital era 4.0, social media platforms and video-forming elements that can arouse consumers' emotions and desire to visit must be considered, so that messages and promotional objectives can be conveyed properly to consumers. This study aimed at analyzing the potential of Bali tourism promotion through digital video marketing so that it can be used as a strategy that is suitable for the current digital era.This research using qualitative and quantitative methods (mixed methods) in which the data were collected through interviews and questionnaires. The effectiveness of the video was calculated using CRI (Customer Response Index) by implementing AISAS concept. Incidental quota sampling was done to determine the research sample. The research was done on Facebook. The collected data were analyzed using digital marketing theories, AISAS, and the theories of tourism promotional video. The results showed that the five among six selected videos were uploaded to Facebook are considered effective in conveying the promotional messages. There was a video with a high value of CRI AIS in which it will directly affect the videos' virality because of the high numbers of shares. The videos' virality will boost the videos' popularity that has a significant relationship to the destination's popularity. A popular video is powerful enough to arouse the desire of consumers to visit a destination. This study found a relationship between the CRI AIS value with the level of motivation and consumer desire to visit. The higher the CRI AIS value, the higher the level of motivation to visit.
\end{abstract}

Thisisan open accessarticleundertheCC BY-SAlicense.

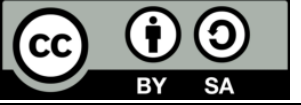

CorrespondingAuthor:

Herry Arianto,

Tourism Doctoral Program,

J1.Dr. R. Goris no.7 Denpasar, Bali, Indonesia 80114

Email: infopar@unud.ac.id

\section{INTRODUCTION}

Bali with all the uniqueness of its culture and people, combined with the harmonization of the exoticism of the natural scenery and the creativity of the people, can be the basic capital for tourism development that has a competitive advantage. Bali with all the charms of tourist attractions until now still has a lot of tourism potential that can still be developed to increase tourist visits. One way to introduce the Bali area that has not yet been exposed is through promotion. Promotion is one of the important strategies that need to be considered to increase the number of tourists. Based on data from the Bali Province Central Statistics Agency, the growth of foreign tourists to Bali in 2018 - 2019 decreased by $3.47 \%$ compared to $2017-2018$.

The decrease in tourist numbers needs to be well identified and better promotion is needed. Promotion strategies in tourism have changed drastically influenced by the development of science and technology. Currently, various digital promotion strategies have been created. Digital marketing is a promotional strategy using the internet and information technology to expand and improve conventional marketing functions (Urban, 2004: 2). The Internet is the most powerful and most effective promotional tool. Advances in technology and the internet are now being used by tourists to get tourism information using digital media. 
Based on data from the Indonesian Internet Service Providers Association (APJII) and Hootsuite We Are Social, the number of internet users in Indonesia is very high. Internet users increase every year, in 2020 the number of internet users was 175.4 million people and in 2021 it is increased to 202.40 million people. In Bali, specifically, $59 \%$ of the total population uses the internet. The majority of internet users are people who fall into the category of digital natives, namely the generation born after 1980 (when digital social networking technologies such as Usenet and bulletin board systems were born) or born in the internet era, grew up with broad access to technology, and intuitively capable to use the information technology devices and navigating the internet (Palvrey and Gasser, 2013).

The development of technology and information as well as the increase in internet users should be considered by stakeholders in promoting Bali tourism. However, the current reality is that Bali tourism stakeholders do not take advantage of advances in technology and information and the internet in carrying out promotions. The $\mathrm{CEO}$ of Hakuhodo International Indonesia (digital advertising) stated that he had never remembered any Bali tourism promotions that were officially made by stakeholders who are responsible for Bali tourism (Ramli interview, May 2021). Even though the video exists and is widely circulated on social media, it means that the tourism video is less effective because it cannot attract the attention of the audience.

In digital marketing, besides the internet, video content plays an important role in promotional media. Video is a medium for delivering messages that contain audio-visual elements (including animation), with the touch of the computer system, viewers can not only hear, see or read, but can also provide an active response (Seels and Glasgow in Arsyad, 2006: 36). Video as an interactive medium is good in delivering messages because it has multiple effects, including cognitive, affective, and psychomotor. Cognitive, affective, and psychomotor effects arising from the audio and visual elements in the video will make the message transmitted easily to the viewers or audiences (Anderson, 1987: 104). Regarding this, video can be considered as a form of promotion that can provide benefits in increasing sales.

Video marketing as a tourism promotion strategy is considered to be very effective and optimal for use in this current digital era. Video marketing is a strategy for distributing electronic messages in the form of videos containing audio and visual elements by using an internet connection through social networks. By using video marketing, the message that will be conveyed to potential customers will be faster and easier to absorb. In addition, the promotion delivered through video with the creativity and innovation contained in it will be easier to publish or share with others through social media. Bali as a world tourist destination requires an up-to-date promotion strategy, following the changes of times, technology, and knowledge to be able to make positive impacts on tourism development. There was no research proving the effectiveness of digital video as a medium for promoting Bali tourism in the current digital era, and then a study entitled "The Effectiveness of Bali Tourism Promotion through Digital Video Marketing" was carried out.

\section{METHODS}

The research method used was a mixed method of Concurrent Transformative Strategy, with qualitative and quantitative approaches. The qualitative approach was done through in-depth interviews with experts to describe Bali tourism, the development of Bali tourism promotion, and the development of current Bali tourism promotion techniques/strategies. Meanwhile, the quantitative approach was used to measure the effectiveness of videos requiring data in the form of numbers to be processed, tested, and transformed into information. The research was done on Facebook. The objects of the research were videos describing Bali tourism, which are uploaded by media/pages or communities with a good level of public interaction, such as the number of views, likes, comments, and high shares. Qualitative data were collected through observation, interviews, and literature study. Quantitative data weregained by distributing online questionnaires.

Observations were done by analyzing the phenomena occurring on social media (Facebook) related to the promotion of Bali tourism. The most important factor in the observation technique was the observer and the person/object being observed, which also plays a role as an information source, namely the informant (Adler, 2009: 523-524). In-depth interviews were conducted to obtain various information related to tourism promotion, digital marketing, and video marketing. The interviewer was assisted by a list of questions that had been prepared. The informants of the interview were experts in the field of Bali tourism, such as the government (tourism), cultural experts, Bali promotion agencies, content creators, digital marketing (video marketing) experts, and academics.

The literature study was carried out to find out the information related to research problems that were based on the exploration of various texts, manuscripts, books, and documents related to the research title. The online questionnaires were distributed to the samples, in this case, Facebookers (active users of Facebook, especially those leaving a digital footprint) through Facebook Messenger. The sampling technique used was incidental quota sampling, Facebook users who have seen videos about Bali and left a digital trail who incidentally were willing to voluntarily answer the questionnaires. 
International Journal of Social Science (IJSS)

Vol.1 Issue.5 February 2022, pp: 553-562

ISSN: 2798-3463 (Printed) | 2798-4079 (Online)

Validity tests and data reliability tests were conducted to measure the validity of the questionnaires. Based on the results of the validity test, it showed that 5 questions have a calculated R-value greater than 0.197 . The reliability test in this study was carried out using SPSS for windows version 20.00 program with the Cronbach Alpha method.

Table 1. The Results of Reliability Test

\begin{tabular}{|c|c|c|c|}
\hline Video & $\begin{array}{c}\text { Alpha } \\
\text { Cronbach }\end{array}$ & $\begin{array}{c}\text { Standard } \\
\text { Value }\end{array}$ & Conclusion \\
\hline 1 & 0,743 & 0,6 & Reliabel \\
\hline 2 & 0,789 & 0,6 & Reliabel \\
\hline 3 & 0,752 & 0,6 & Reliabel \\
\hline 4 & 0,747 & 0,6 & Reliabel \\
\hline 5 & 0,704 & 0,6 & Reliabel \\
\hline 6 & 0,712 & 0,6 & Reliabel \\
\hline
\end{tabular}

Source: SPSS Analysis, 2021

The data obtained through questionnaires are described descriptively using the CRI (Customer Response Index) model by implementing the AISAS concept (Attention, Interest, Search, Action, Share) to measure the effectiveness of advertising from a Bali tourism promotion video. AISAS components in the questionnaire were measured using a dichotomous scale. The weight assessment of the questions was done by giving a list of questions to the respondents that were answered based on the following weights (a) Yes $=1$, (b) No $=0$.

$\boldsymbol{C R I}=$ awareness $x$ comprehend $x$ interest $x$ intentions $x$ action

$\boldsymbol{C R I}=$ attention $x$ interest $x$ search $x$ action $x$ share

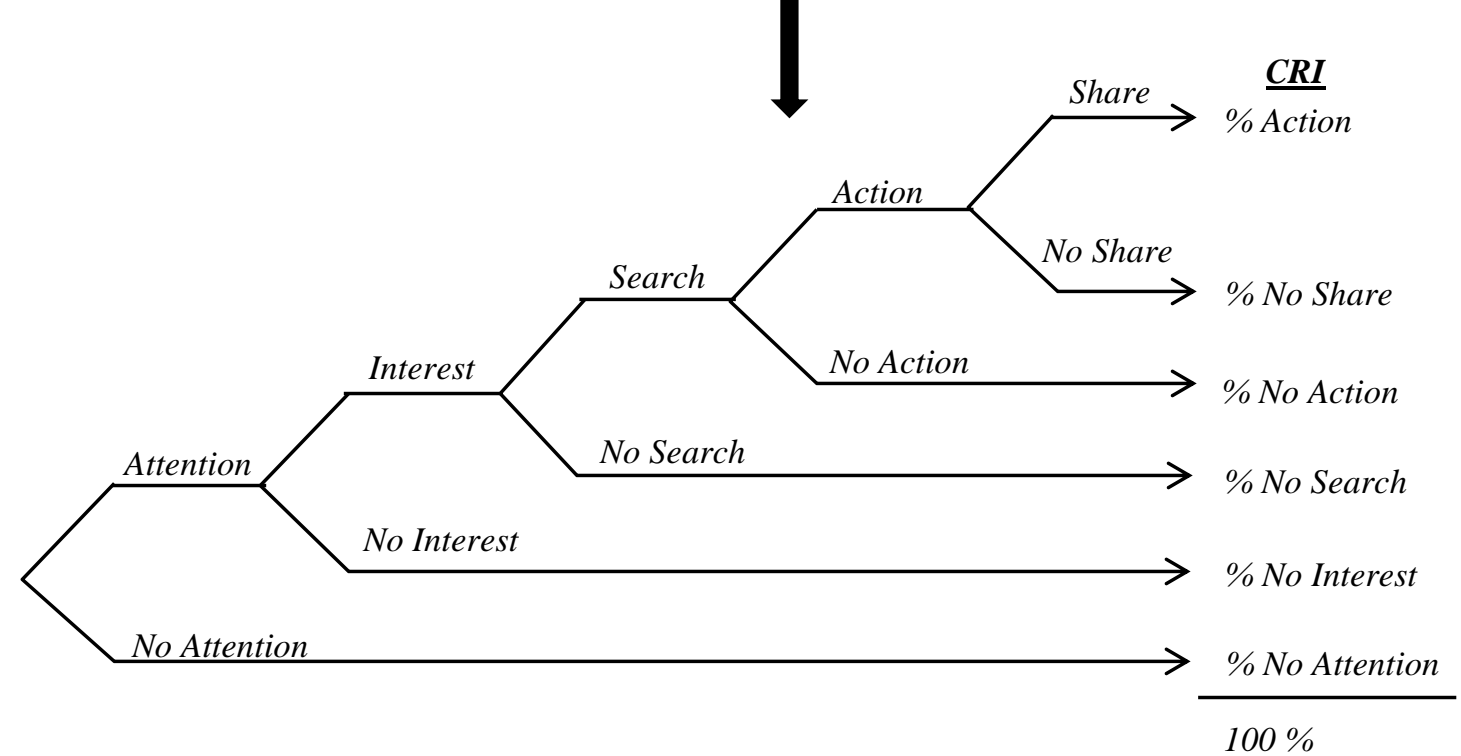

Picture 1. CRI model (the implementation of AISAS)

Source: Durianto, et.al., 2003: 49

\section{RESULTS AND DISCUSSION}

The research of Effectiveness of Bali Tourism Promotion through Digital Video Marketing was done on Facebook. Six videos were selected on Facebook with Balinese tourism content that has a good level of public interaction (high number of views, likes, comments), including Video 1 entitled "Lempuyang Luhur: Temple in the Sky" (7,800 likes, 552 comments, 1,056, 379 views until April 9, 2021), Video 2 entitled "I Need to Visit Bali: Someone Please Take Me Island Hopping in Bali" (27,000 likes, 7,700 comments, 903,000 views), Video 3 entitled 
"Beautiful Bali: Bali is Stunning" (41,000 likes, 7,000 comments, 764,000 views), Video 4 entitled "Someone Take Me to Bali: Bali Should Definitely Be On Your Bucket List" (38,000 likes, 10,000 comments, 848,000 views), Video 5 entitled "Exploring Beautiful Bali: Someone Take Me to Bali" (21,000 likes, 5,500 comments, 393,000 views), and Video 6 entitled "Kelingking Beach, Nusa Penida, Bali" (68,000 likes, 3,100 comments, 2,600,000 views). The sample taken was 100 viewers for each video leaving the digital footprint in the video.

Before analyzing the potential of Bali tourism promotion through digital video marketing, the discussion about digital video as a promotional medium should be clearly explained first. According to Dwyer (Sadiman, 1996), video can seize $94 \%$ of the channel for transforming messages or information into the human psyche through the eyes and ears and it can make people, in general, remember $50 \%$ of what is seen and heard from video. In line with Dwyer's opinion, of the 16 sources, all of them (100\%) stated that video media has great potential in influencing people, its capabilities in conveying messages or information to audiences. In addition, considering the development of the digital world today, digital video marketing is considered very effective to use as a marketing medium.

Promotion using video marketing also plays a role in expanding the target market to infinity. The whole world can see the video marketing that has been made so that the potential market reach will be very large and wide. The ease of accessing the internet has now made the opportunity to inform it to the international scope easier. As one of the countries with the most social media users in the world, the appropriate form or marketing strategy should be the existence of social media as a platform for distributing promotional content. In this case, social media can make it easier for users to connect with other users, participate and contribute, and help people communicate with many parties without experiencing the limitations of space and time (Karjaluoto, 2008).

Related to tourism promotion, the use of digital videos and social networks is a kind of innovation in the promotional strategies that are considered very important in supporting tourism promotion. Video has a very strategic role for marketing purposes, including the tourism business because it has a positive influence on the image of the destination of a tourism area (Damanik et al, 2019). Positive perceptions of tourist destinations shown in videos can affect personal motivation and decision-making processes. A positive image produces a positive impression of the destination in the minds of tourists and will affect the behavior of tourists in the future (Chen and Tsai, 2007). This study does not find out a direct relationship between watching videos and visiting destinations mentioned by videos on the internet, but this will measure the potential of digital video marketing in promoting Bali tourism is by calculating the effectiveness of videos using CRI (Customer Response Index) which applies the AISAS concept.

Attention, Interest, Search, Action, and Share (AISAS) is a model of online consumer behavior, which is the development of the traditional consumer behavior patterns of AIDMA/Attention, Interest, Desire, Memory, and Action model of marketing (Chen and Huang, 2012). Due to changes in consumer behavior patterns driven by the development of information and communication technology, namely the internet, the digital era, or online, the AISAS model is considered more relevant to be used nowadays (Sugitama and Andree, 2011). The effectiveness of the video shows the extent to which the effect of the video message conveyed can attract attention, be understood, arouse emotions, and lead the target to provide the desired response (Effendy, 2002). Thus, a video that is more eyecatching, understandable, and more able to arouse the emotions of viewers will increase the popularity of the video which is closely related to the popularity of the destination.

The data of the questionnaires that were distributed to 600 respondents were put into a table and stated the detailed number of respondents who filled out each question. The analysis of the frequency distribution of Attention, Interest, Search, Action, and Share is as follows. The frequency of the attention stage to Bali tourism messages can be seen in Table 2 .

Table 2. Attention Frequency

\begin{tabular}{|c|c|c|c|c|c|c|c|}
\hline \multirow{2}{*}{ Attention } & \multicolumn{6}{|c|}{ Numbers } & \multirow{2}{*}{ Total (\%) } \\
\cline { 2 - 7 } & Video 1 & Video 2 & Video 3 & Video 4 & Video 5 & Video 6 & \\
\hline Yes & 79 & 47 & 65 & 61 & 57 & 73 & $64 \%$ \\
\hline No & 21 & 53 & 35 & 39 & 43 & 27 & $36 \%$ \\
\hline
\end{tabular}

Source: The results of the questionnaire, 2021

Based on the results of the questionnaire related to the respondents' reasons for not paying attention to videos about Bali, $85 \%$ of the respondents have never watched videos about Bali, but there are many videos about natural beauty, tourist attractions, culture, customs/traditions, as well as the culinary variety of other islands or other countries and 15\% respondents said they rarely watched videos on online media accounts and were only interested in 
International Journal of Social Science (IJSS)

Vol.1 Issue.5 February 2022, pp: 553-562

ISSN: 2798-3463 (Printed) | 2798-4079 (Online)

DOI: https://doi.org/10.53625/ijss.v1i5.1294

reading or hearing news about Bali. The frequency of respondents' interest in Bali tourism messages can be seen in Table 3. The respondents were not interested in videos about Bali because they thought they do not need what is shown in the videos. Furthermore, the video content/materials have been seen very often.

Table 3. The Frequency of Interest

\begin{tabular}{|c|c|c|c|c|c|c|c|}
\hline \multirow{2}{*}{ Interest } & \multicolumn{6}{|c|}{ Numbers } & $\begin{array}{c}\text { Total } \\
(\%)\end{array}$ \\
\hline & Video 1 & Video 2 & Video 3 & Video 4 & Video 5 & Video 6 & \\
\hline Yes & 66 & 26 & 44 & 53 & 41 & 64 & $77 \%$ \\
\hline No & 13 & 21 & 21 & 8 & 16 & 9 & $23 \%$ \\
\hline
\end{tabular}

Source: The results of the questionnaire, 2021

The frequency of the search stage for Bali tourism messages can be seen in Table 4. There are two reasons why the respondents did not search videos about Bali, namely the content or material in the video has been seen very often and has visited and or bought and or tried the objects offered in the video.

Table 4. The Frequency of Search

\begin{tabular}{|c|c|c|c|c|c|c|c|}
\hline \multirow{2}{*}{ Search } & \multicolumn{6}{|c|}{ Numbers } & \multirow{2}{*}{$\begin{array}{l}\text { Total } \\
(\%)\end{array}$} \\
\hline & Video 1 & Video 2 & Video 3 & Video 4 & Video 5 & Video 6 & \\
\hline Yes & 32 & 17 & 11 & 33 & 23 & 44 & $65 \%$ \\
\hline No & 31 & 6 & 18 & 10 & 12 & 11 & $35 \%$ \\
\hline
\end{tabular}

Source: The results of the questionnaire, 2021

The frequency of the action stage on Bali tourism messages can be seen in Table 5. There are two main reasons for not performing any action to visit any destination in Bali are having bad experiences with objects in the video and time and cost constraints.

Table 4. The Frequency of Action

\begin{tabular}{|c|c|c|c|c|c|c|}
\hline \multicolumn{7}{|c|}{ Frequency of Actionfrom the $2^{\text {nd }}$ question } \\
\hline \multirow{2}{*}{ Action } & \multicolumn{6}{|c|}{ Jumlah } \\
\hline & Video 1 & Video 2 & Video 3 & Video 4 & Video 5 & Video 6 \\
\hline Yes & 0 & 0 & 0 & 2 & 1 & 0 \\
\hline No & 0 & 1 & 0 & 2 & 2 & 0 \\
\hline \multicolumn{7}{|c|}{ Frequency of Actionfrom the $3^{\text {rd }}$ question } \\
\hline \multirow[b]{2}{*}{ Action } & \multicolumn{6}{|c|}{ Jumlah } \\
\hline & Video 1 & Video 2 & Video 3 & Video 4 & Video 5 & Video 6 \\
\hline Yes & 3 & 3 & 0 & 2 & 5 & 4 \\
\hline No & 20 & 10 & 0 & 15 & 10 & 14 \\
\hline Yes & 3 & 3 & 0 & 4 & 6 & 4 \\
\hline No & 20 & 11 & 0 & 17 & 12 & 14 \\
\hline
\end{tabular}

Source: The results of the questionnaire, 2021 
The frequency of the sharing stage for Balinese tourism messages can be seen in Table 6. There are two reasons why the respondents do not share the videos that not willing to give feedback on other people's work and have unpleasant experiences when visiting objects offered in the video.

Table 6. The Frequency of Share

\begin{tabular}{|c|c|c|c|c|c|c|}
\hline \multicolumn{7}{|c|}{ The Frequency of Sharefrom question 2} \\
\hline \multirow{2}{*}{ Share } & \multicolumn{6}{|c|}{ Numbers } \\
\hline & Video 1 & Video 2 & Video 3 & Video 4 & Video 5 & Video 6 \\
\hline Yes & 3 & 2 & 12 & 2 & 3 & 9 \\
\hline No & 0 & 0 & 3 & 5 & 0 & 0 \\
\hline \multicolumn{7}{|c|}{ The Frequency of Sharefrom question 3} \\
\hline \multirow{2}{*}{ Share } & \multicolumn{6}{|c|}{ Numbers } \\
\hline & Video 1 & Video 2 & Video 3 & Video 4 & Video 5 & Video 6 \\
\hline Yes & 33 & 6 & 17 & 17 & 9 & 35 \\
\hline No & 10 & 3 & 12 & 4 & 8 & 2 \\
\hline \multicolumn{7}{|c|}{ The Frequency of Sharefrom question 3} \\
\hline \multirow{2}{*}{ Share } & \multicolumn{6}{|c|}{ Numbers } \\
\hline & Video 1 & Video 2 & Video 3 & Video 4 & Video 5 & Video 6 \\
\hline Yes & 11 & 7 & 0 & 18 & 15 & 17 \\
\hline No & 12 & 7 & 0 & 3 & 3 & 1 \\
\hline Yes & 47 & 15 & 29 & 37 & 27 & 61 \\
\hline No & 22 & 10 & 15 & 12 & 11 & 3 \\
\hline
\end{tabular}

Source: The results of the questionnaire, 2021

After getting the results of the questionnaire distributed to 100 respondents in each video (a total of 600 respondents), to find out the answer choices and reasons related to AISAS in each video, the Customer Response Index (CRI) was calculated to determine the effectiveness of the six tourism marketing videos Bali selected on the Facebook. CRI calculations was carried out on four possible response processes that can occur because the stages in AISAS can be done, including the calculation of AISAS (attention-interest-search-action-share), AISS (attentioninterest-search-share), AIAS (attention-interest-action-share), and AIS (attention-interest-share).

Based on CRI calculations that have been carried out on six selected videos and linked to the theory of effectiveness, it can be concluded that five of the six Bali tourism promotion videos uploaded on Facebook are considered effective in conveying promotional messages to their viewers. This can be seen from the attention and interest values that exceed 50\% (consumer responses below 50\% including low values (Durianto, 2003: 50), produced by videos $1,3,4,5$, and 6 . The highest attention value was achieved by video 1 entitled Lempuyang Luhur "Temple in the Sky". Of the total 100 respondents to video 1, there were 79 respondents (79\%) who answered "yes, have seen the video on online media platforms" while only 21 respondents (21\%) ) who answered "never".

The highest interest value was achieved by video 6 entitled Kelingking Beach, Nusa Penida, Bali. Of the 73 respondents who have seen the video, there were 64 respondents $(88 \%)$ who were interested in the video, and only 9 respondents (12\%) were not. Meanwhile, in terms of the effectiveness of video marketing, video 2 entitled I Need to Visit Bali was the least effective in conveying video messages to the audiences because based on CRI calculations, the value of no attention (53\%) and value of no interest (45\%) were high. The results of the CRI calculation showed that the dominant consumer responses were not linear. The AISS (attention-interest-search-share) and AIS (attentioninterest-share) models are the stages that many respondents went through.

Based on the CRI calculations of the six selected videos, in general, respondents' responses to the final stage that is shared were still classified as having a low value, which was below 50\%. Only video 6 entitled Kelingking Beach, Nusa Penida, Bali has a good share that was about $61 \%$. This indicates the need to improve the quality of video including the content/material, the completeness of information, the image and sound quality, and narration that can lead respondents to share the video. This is related to Sugitama \& Andree (2011: 78) mentioning that information is one of the factors in purchasing decisions in the current internet era. 
International Journal of Social Science (IJSS)

Vol.1 Issue.5 February 2022, pp: 553-562

ISSN: 2798-3463 (Printed) | 2798-4079 (Online)

DOI: https://doi.org/10.53625/ijss.v1i5.1294

It can be concluded that digital video marketing is the potential to be used as a medium for promoting Bali tourism. In terms of video effectiveness, based on CRI calculations, high attention and interest values were obtained (more than 50\%). This high attention and high interest will affect the high consumer response to take action or the next stage: search, action, share. This is happening to video 1 and video 6. Based on the results of the CRI AISAS calculation, Video 6 "Kelingking Beach, Nusa Penida, Bali" has the highest CRI AIS score (61\%) among the other 5 videos. The high CRI AIS value indicates that Video 6 is informative and effective in conveying video messages to the audiences (the audiences do not need to go through the search process). Consumers skipped the action stage, but they directly share. The skipping of the consumer response action stage to the video based on the results of the questionnaire was caused by the limited time and cost. Then it will not be discussed further (no relation to the video elements).

The video of Kelingking Beach, Nusa Penida, and Bali can be considered to have the ability to evoke the audiences' emotions and influence the audiences' behavior to re-share the videos that have been watched. It is proven by video 6 having the highest share rate among the other 5 videos, which is 30,000 shares (until April 9, 2021) on Facebook. The high CRI AIS value as was proven by the high video share rate on Facebook will directly support the virality of the video. This means the video will spread quickly or be shared repeatedly by Facebook users (viral video). The faster it spreads and the more people re-share the video on social media, the higher/better the popularity of the video will be.

Popular videos have a high number of viewers (viewers) and feedback on videos (likes/dislikes, comments, shares, favorites, and subscriptions). The higher the number of videos and the feedback generated by the videos, the destination promoted through the videos will be more popular since there is a strong relationship between the popularity of the video and the popularity of the destination (Bremner, 2015). The popularity of the destination will be able to influence the motivation and desire of tourists to visit the destination promoted in the video. So it can be concluded that the CRI AIS value will affect the level of motivation and consumer desire to visit the destination shown in the video.

\section{CONCLUSION}

Video has the potential to be used as a marketing medium because of its capabilities to influence the emotions of the audiences. There is no research proving the direct relationship between watching videos and visiting destinations with videos on the internet. However, one way to measure the potential of digital video marketing in promoting Bali tourism is using CRI (Customer Response Index). Based on CRI's calculation of the six videos used as research objects, it can be concluded that five out of the six Bali tourism promotion videos uploaded on Facebook can be considered effective in conveying promotional messages to the audiences.

It is proven by the high value of attention and interest (more than 50\%) generated by videos $1,3,4,5$, and 6 . This high attention and high interest will affect the high consumer response to take action or the next stage (search, action, share). The results of the CRI calculation also show that the dominant consumer response was not linear, the AISS (attention-interest-search-share) and AIS (attention-interest-share) models are the stages that many respondents went through. Optimizing the effectiveness of digital video as a means of promotion needs to be done by minimizing and tackling various factors leading the audiences to not pay any attention, not showing any interest, not searching, not performing action, and not sharing the videos they watch.

The high value of CRI AIS on one of the videos indicates the role of the video can increase the emotions of the audiences and influence the behavior of the audience to re-share the videos that have been watched. It is based on the high share rate of video 6 on Facebook. The high CRI AIS value will directly increase the virality of the video. The virality of the video based on the high CRI AIS value will contribute to the popularity of the video. Video popularity has a strong relationship with destination popularity. A popular video can increase audiences' desire to visit a destination.

\section{RECOMMENDATION}

To analyze the effectiveness of Bali tourism promotion videos, the researcher researched Facebook. Based on this, analysis of the effectiveness of advertising (video marketing) on other social media such as Instagram, Youtube, and TikTok needs to be studied to enrich the results of research in the field of video marketing. Based on the deeper understanding, the promotion of tourism in Bali is a complex activity but it is very important to do so it needs to be considered carefully. Digital video marketing in promoting Bali tourism uploaded through social media is considered very appropriate to be used in this digital era and is expected to increase the number of tourists. 
Bali tourism is very diverse, but the possibility of stagnation should be anticipated. Video marketing is one of the best ways to promote new tourist attractions in Bali which can avoid the stagnation of Bali tourism. Opportunities that can be explored to develop the tourism sector in Baliare by exposing North Bali tourism which has a lot of tourism potential. Besides, new forms of Bali tourism (not only relying on natural, cultural, culinary attractions) need to be explored as well to maintain the image of the tourism sector in Bali.

The government is expected to be able to promote Bali tourism by using digital video marketing that implements video-forming elements to attract the interest and motivation of potential tourists to video content.

This aim is to ensure that marketing objectives are transformed properly. Social media can facilitate the implementation of promotional activities (either intentionally or unintentionally). Social media users can easily participate, share, load content (images and videos), and write the beauty, uniqueness, and attractiveness of a Bali tourist destination to the general public through online platforms. For this reason, it is necessary to think about a good collaboration between the developers of Bali tourism promotion (government/private) and millennials as social media users to promote Bali tourism.

During the Covid-19 pandemic, people are expected to stay at home. This leads people to spend more time with electronic devices (smartphones, laptops, tablets, and smart TVs) and increase online activities. Online activity, in terms of watching videos, is $90 \%$ and is the largest activity carried out during the pandemic compared to other online activities (We Area Social and Hootsuite, 2020). Skilled marketers should be able to take advantage of this opportunity to continue promoting Bali tourism. Even though people who watch the video will not immediately buy or visit Bali, but marketers can start to instill how attractive Bali tourism is, and make Bali the main option of destination that must be visited by tourists once the Covid-19 pandemic is over. This allows tourism promoters to continue to create memorable promotional content in the minds of tourists.Bali tourism promotion should show serious action to prevent the spread of the virus during holidays or visits, such as tourism destinations and hotels have implemented health protocols for visitors and carry out fogging of disinfectants regularly and provide information regarding the requirements that must be carried out to visit Bali such as PCR test and vaccine declaration. This video related to health and Covid-19 protection can further convince tourists to travel safely to Bali.

\section{ACKNOWLEDGEMENTS}

I thank Deddy, Steffany, Feby, for their assistance in data measurements and analyses.We thank the all mentor for their useful sugestions. Thank you for my lovely wife Ariani Siswanto, my precious son Josephe, Josiah, Jehoshua for their continuous support and encouragement for my pursuit.

\section{REFERENCES}

[1] Adler, Patricia A and Adler, Peter. 2009. Teknik-Teknik Observasi dalam Handbook of Qualitative Research. Pengarang Norman K. DenzimandYvonna S. Lincoln. Yogyakarta: Pustaka Pelajar.

[2] Anderson, Ronald H. 1987. Pemilihan dan Pengembangan Media untukPembelajaran. Jakarta: CV Rajawali.

[3] APJII. 2015. Penggunaan Internet di Indonesia. Hasil survey APJII (Asosiasi Penyelenggara Jasa Internet Indonesia) yang bekerja sama dengan Pusat Kajian Komunikasi (Puskakom) Universitas Indonesia.

[4] _.2017. Survei Internet APJII 2016. Jakarta: APJII dan Polling Indonesia.

[5] 2018. Laporan Survei Penetrasi dan Profil Perilaku Pengguna Internet Indonesia Survei 2017. Jakarta: APJII dan Teknopreneur Indonesia.

[6] _.2019. Laporan Survei Penetrasi dan Profil Perilaku Pengguna Internet Indonesia Survei 2018. Jakarta: APJII dan Polling Indonesia.

[7] ArsyadAzhar. 2006. Media Pembelajaran. Jakarta: Raja Grafindo Persada.

[8] Badan Pusat Statistik. 2019. Jumlah Wisatawan Asing ke Bali Menurut Bulan, 1982-2019. (serial online). [cited 2019 Des. 4]. Available from URL: https://bali.bps.go.id/statictable/2018/02/09/21/jumlah-wisatawan-asing-kebali-menurut-bulan-1982-2019.html.

[9] Bremner, C. 2015. Top 100 City Destinations Ranking. (serial online). [cited 2019 Sep. 25]. Available from URL: http://blog.euromonitor.com/2015/01/ top-100-city-destinations-ranking.html

[10] Chen, Ching-Fu and Tsai, Dung Chun. 2007. "How Destination Image and Evaluative Factors Affect Behavioral Intentions?". Tourism Management. Vol. 28(4): 1115-1122.

[11] Durianto, dkk. 2003. Invasi Pasar dengan Iklan Yang Efektif. Jakarta: PT Gramedia Pustaka Utama.

[12] Karjaluoto, E. 2008. A Primer in Sosial Media. London: A Smash LAB White Paper.

[13]Effendy, Onong U. 2002. Ilmu Komunikasi: Teori dan Praktek. Bandung: PT Remaja Rosdakarya.

[14] Palfrey, John dan Gasser, Urs. 2008. Born Digital Understanding The First Generation of Digital Natives. New York: Basic Book.

[15] Sugitama, Kotara dan Andree, Tim. 2011. The Dentsu Way. New York: McGraw-Hill. 
International Journal of Social Science (IJSS)

Vol.1 Issue.5 February 2022, pp: 553-562

ISSN: 2798-3463 (Printed) | 2798-4079 (Online)

DOI: https://doi.org/10.53625/ijjss.v1i5.1294

[16] Urban, Glen L. 2004. Digital Marketing Strategy: Text and Cases. New Jersey: Pearson Prentice Hall. 
